\title{
Signs as Houses (Places) in Ancient Astrology
}

\section{Robert Hand}

\begin{abstract}
Previous work in the study of ancient horoscopes (Neugebauer, van Hoesen, North et al.) has suggested that ancient writers were deficient in their computations of horoscopes regarding the computation of the Midheaven degree and the cusps of 'places' or 'houses'. This paper suggests that such was not necessarily the case and that these sources used the zodiacal signs, themselves, as 'places' and did not (with a few late exceptions) even try to compute the second twelve-fold division independent of the signs. The charts included in Neugebauer and van Hoesen's Greek Horoscopes, and in Jones' Astronomical Papyri from Oxyrhynchus (which include the bulk, if not all of, our surviving collection of ancient charts) are used as the basis of this research. Ptolemy and Julius Firmicus Maternus are also discussed for their apparent views on 'places'. Examples are provided that suggest that this practice survived into the medieval Arabic tradition.
\end{abstract}

\section{The Problem}

It is generally known that in ancient, medieval, and modern astrology, a properly constructed astrological chart divides the ecliptic into twelve zones in two different ways. In modern astrology the first method of dividing into the twelve zones creates the signs of the zodiac; the second method creates what are called, in modern astrology at least, the houses. But in ancient and also in much of medieval astrology what we now call 'houses' were called 'places' (Greek $\tau$ ó $\pi \mathrm{ol}$, Latin loci). ${ }^{1}$ The term 'house' (Greek oikos, Latin domus) at that time was used to designate a sign whenever that sign was referred to in relation to the one or more planets that were believed to 'dispose of', in some way rule or govern, or merely be at home in that sign. Such a planet was called 'ruler' or 'lord' of the

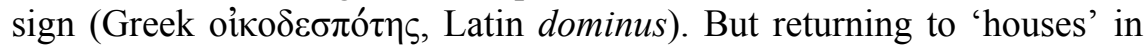

\footnotetext{
${ }^{1}$ German still uses der Ort as well as das Haus for these divisions in astrological terminology.
}

Robert Hand, 'Signs as Houses (Places) in Ancient Astrology', Culture And Cosmos, Vol. 11 no 1 and 2, Spring/Summer and Autumn/Winter 2007 pp. 135162.

www.CultureAndCosmos.com 
the modern sense J. D. North characterises houses (following modern usage) as follows:

[houses]... are the divisions of ecliptic...that depend on the way this [the ecliptic] is cut at the moment of birth, or whatever, by the horizon and meridian. The rising point of the ecliptic, which turns as a whole with the daily rotation, is the ascendent (ascendens, horoscopus, ஸробко́ $\pi$ o)). The twelve houses are usually counted from this point, working in the direction of increasing longitude. $^{2}$

From here on, however, I will be using the ancient convention of referring to these divisions as 'places' rather than 'houses', unless explicitly stated otherwise.

As North and others have pointed out, methods of computing the beginnings of the places (cusps) have been a bit of a mess (my characterisation), as astrologers from the ancient world to the present have disagreed on the proper method for doing this. But historically speaking, if one ignores Roman era Greek sources (which are the focus of this paper), computations of the cusps of the places have fallen into two general categories of method. One method is to begin each place subsequent to the first place at $30^{\circ}$ intervals from the rising degree or ascendant ${ }^{3}$ so that the beginning of each subsequent place has the same degree as the ascendant in each of the following signs. North refers to this as the 'Single Longitude method'. ${ }^{4}$ Modern astrologers designate it as the 'Equal House' system, and it was known in Latin as modus equalis (the term I shall use in this paper). The other general method is to compute the ascendant which also in turn determines the setting degree or descendant (exactly opposite the ascendant in longitude) as well, then to compute the midheaven (Greek $\mu \varepsilon \sigma o u p \alpha ́ v \eta \mu \alpha$, Latin medium coeli) which also gives rise to the opposite, anti-culminating point of the ecliptic, the I.C. (Greek

\footnotetext{
2 J. D. North, Horoscopes and History (London, 1986) [hereafter North], p. 1.

${ }^{3}$ There are two common spellings of this word, 'ascendant' and 'ascendent'. The former is more common among astrologers and in popular writing. The latter is more etymologically correct as the Latin word is ascendens. I follow the astrological convention here.
}

${ }^{4}$ North, p. 6. 


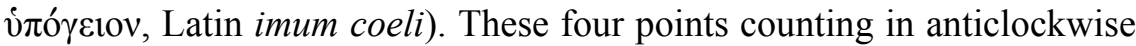
order starting with the ascendant, mark off the beginning of the cardinal, or angular places, the ascendant marking the first place, the I.C. the fourth place, the descendant ${ }^{5}$ the seventh place, and the midheaven the tenth place. The other places are then derived by trisecting the quadrants (which are usually more or less than $90^{\circ}$ ) thus formed by an amazing variety of methods, none of which have any clear theoretical basis. These methods range from a simple trisection of each quadrant in ecliptic longitude (attributed to Porphyry), ${ }^{6}$ to the very complex system advocated by Maginus and Placidus in early modern times, the so-called Placidian system. ${ }^{7}$ The most common systems used prior to early modern times were the so-called Porphyry system and the system western

\footnotetext{
${ }^{5}$ Following the same spelling convention as 'ascendant'.

6 The method is found in an introduction to Ptolemy attributed to Porphyry (CCAG 5/4, p. 226; see also the 1559 Basel edition, Porphyii Philosophi introductio in Ptolemaei opus de effectibus astrorum, p. 203 [this work also contains the anonymous Commentary on the Tetrabiblos and 'Hermes', De revolutionibus nativitatum]), but in that work it is actually quoted from a dictionary of astrological terms attributed to Antiochus of Athens (probably $2^{\text {nd }}$ century CE) which was used by Porphyry. The method appears also in Vettius Valens' Anthology (III, 2) which may be an earlier work than that of Antiochus. For an English translation of the same passage see Antiochus of Athens, The Thesaurus, trans. Robert Schmidt (Berkeley Springs, WV, 1993), p. 32. For the Vettius Valens reference see Vettius Valens, The Anthology, Book II (concl.) \& Book III, trans. Robert Schmidt (Berkeley Springs, WV, 1994), pp. 33 ff. (= III,
} 2, pp. 127-28 Pingree).

${ }^{7}$ This system trisects diurnal and nocturnal semi-arcs of ecliptic degrees such that the ascendant is the beginning of the first place. The twelfth place (preceding the first in the order of the signs) begins at that ecliptic degree which is one-third of its own way from ascending to culminating. The eleventh place begins at the degree which two-thirds of its way from ascending to culminating. Then the second place which follows the first in the order of the signs begins at that ecliptic degree which is two-thirds of its way from anti-culminating to ascending; and the third place begins at that degree which is one-third of its way from anti-culminating to ascending. The culminating degree of the ecliptic is the midheaven and is the beginning of the tenth place. Thus we have the cusps for places $10,11,12,1,2$, and 3 . The remaining six houses begin at the degrees of longitude exactly opposite these six. The mathematics of this system is exceedingly complex and a rigorous solution can only be obtained by recursion (a series of successive approximations). 
astrologers call the Alcabitius system, ${ }^{8}$ which North refers to as the 'standard system'. Both of these are found in ancient Greek sources, although almost in entirely in later ones, but the standard system is the most common in the Middle Ages, hence North's designation.

However, there is a problem with Roman era sources. As North notes, in the literary charts given in Greek Horoscopes, out of 168 'literary' charts $^{9}$ presented, only 27 give both an ascendant and midheaven (or I.C.). Only two give cusps or 'limits' of the intermediate houses. ${ }^{10}$ Only two of 51 non-literary charts have a midheaven value. North attributes this to a lack of concern for places in Greek astrology, or poor calculation technique. The thesis that I present in this paper is that neither of these accounts for the lack of midheavens and intermediate cusps. I propose that the ancient (and early medieval for that matter) astrologers were in most cases following a very different procedure from that which became standard in later middle eastern and western astrology. They were using the zodiacal signs themselves as places counting the signs from the rising sign, or, in some cases, other points such as the Lot of Fortune, the Sun or the Moon. But before we can examine what they actually may have been doing regarding places, it is necessary to go a bit further into the explanations given by North and the authors of Greek Horoscopes for the lack of midheavens and intermediate cusps.

\section{Missing Midheavens}

The first explanation, that Greek authors did not make much use of places, can be accepted only if one places undue emphasis on Ptolemy, an emphasis that one finds in the history of astrology from the Greeks to the present. Ptolemy certainly uses the places less than most other astrologers throughout the history of astrology, even when compared to other Greek authors. When he does use places, his use is idiosyncratic and

\footnotetext{
${ }^{8}$ This system is found in a chart given in O. Neugebauer and H. B. van Hoesen, Greek Horoscopes (Philadelphia, PA, 1959) [hereafter Greek Horoscopes], pp. 138-40, where it is designated as L428.

${ }^{9}$ I do not follow the practice of referring to astrological charts as 'horoscopes' because that term properly applied means either the ascendant or some other point used to begin reckoning the places. The use of the word 'horoscope' to designate the entire chart is modern, and inappropriate given the original use of the word.
}

${ }^{10}$ North, p. 6. 
nonstandard, ${ }^{11}$ even when we grant that the methods of Greek astrologers were very varied. As the most casual perusal of Greek Horoscopes demonstrates, other authors used places very extensively, even to the point of reckoning places from points other than the ascendant, most especially the Lot of Fortune as mentioned above. ${ }^{12}$

As to the second explanation, that of poor calculation technique, it is of course true that the methods of computation were difficult for the average astrologer in the ancient world to master. It may seem, therefore, very plausible that astrologers were simply too lazy or incompetent to compute the midheaven and the intermediate cusps. However, this manifests a most unhistorical attitude! It is generally agreed that horoscopic astro$\operatorname{logy}{ }^{13}$ emerged at some undetermined date between the conquests of Alexander the Great and the early Roman imperial period. This is a time span of approximately 300 years. Ptolemy (ca. 100-ca.170 CE), who first gave a rigorous solution to the problem of the rising times of the signs, lived after the period of the emergence of horoscopic astrology. In other words, horoscopic astrology developed without the assistance of his superior methods. But even with Ptolemy the emphasis is on the rising times of the signs, which implies the priority of what is rising. While the medieval and modern method of computing the ascendant is to derive an ascendant directly from a midheaven using spherical trigonometry, the ancient method was to compute the position of the Sun for the time of sunrise; that position would have been the ascendant at sunrise. Then, given the elapsed time after sunrise (or sunset, using the position of the

${ }^{11}$ This comment can be made of almost all of Ptolemy's astrology. Modern astrologers who are familiar with Ptolemy are forced to conclude that, despite Ptolemy's stature in the history of astrology, he had much less influence on astrology as practised both in the ancient world and later on, than is generally supposed. His influence seems to have been greatest on theory and on the setting of the tone of what might be called 'scientific' astrology. Otherwise one finds more lip service paid to Ptolemy than actual use of his methods. However, the comparison of the common methods of ancient and medieval astrologers to those advocated by Ptolemy would require a paper in its own right.

${ }^{12}$ For examples of this practice see Manilius, Astronomica, trans. G. P. Goold (Cambridge, MA, 1977), 3.96-204, pp. 171-179, and Vettius Valens, Anthology II, 3, 4, 18, 20 and 21.

${ }^{13}$ Horoscopic astrology means astrology based on a moment of birth or of an event from which is derived a birth or other chart with an ascendant or horoscopus.

Culture and Cosmos 
Sun at sunset for a descendant), one could compute how much of each sign had risen, using the various traditional systems of rising times,${ }^{14}$ and thereby arrive at an approximate ascendant. The main point is that the ascendant was computed directly based on the time elapsed since the nearest previous sunrise or sunset. The computation of a true midheaven, the ecliptic degree culminating exactly in the south on the meridian, was not required and was not a necessary concern. The import of the word 'horoscope' clearly indicates that the ascending degree was regarded from the beginning as the decisive factor.

Why should an ancient astronomer not be concerned with computing the true midheaven as just now defined? Is it not obviously important? First, let us make a point. We need to say that it seems clear from the surviving texts that charts were computed using tables or other computational methods that did not involve direct astronomical observations. Although the methods and tables were cruder than those in use at present, an ancient practicing astrologer was not necessarily any more oriented toward observational astronomy than his modern counterpart. ${ }^{15}$ Nevertheless, those who did make direct observations, those whom we might now call astronomers, would have observed the following:

The point that rises over the horizon due east of an observer is a point on the celestial equator, regardless of what sign or constellation is rising. Except for those times when $0^{\circ}$ or $180^{\circ}$ of longitude are rising (referred to in western astrology as $0^{\circ}$ of Aries, and $0^{\circ}$ of Libra respectively, and by astronomers as the vernal and autumnal equinoctial points), the point rising due east of an observer is not a point on the ecliptic. The rising point of the ecliptic, also known as the ascendant, or anciently as the horoscopus, oscillates north and south of the rising point of the equator. As is known from spherical geometry, when two great circles intersect (both the horizon and ecliptic being great circles), the point $90^{\circ}$ away in either direction from such an intersection is a point of maximum angular separation of the two great circles.

The midheaven, on the other hand, is always by definition a point due south of an observer for anyone living in the northern hemisphere. If one were to see or visualize the interaction of the ecliptic and horizon during the diurnal rotation, one would see that the point of the ecliptic that has

\footnotetext{
${ }^{14}$ Of these the two most common are referred to as System A and System B (see the Introduction to Greek Horoscopes) by historians of ancient astronomy.

${ }^{15}$ See Vettius Valens' Anthology I, 17-18, for various methods by which Valens computed approximate positions of planets without direct observation.
} 
the highest elevation (or altitude) is the point $90^{\circ}$ away (in a westerly direction) from the ascendant, not the midheaven as it is now defined. ${ }^{16}$ Like the ascendant, this point (called the nonagesimal) oscillates, in this case east and west of due south. It is not at all clear that an observer of the motion of the celestial sphere would regard the midheaven as more important than the nonagesimal based simply on visual criteria. The fact that in the course of the evolution of astronomy and astrology the midheaven came largely to supplant the nonagesimal as the other most important point of a chart after the ascendant, does not mean that it was so, or should have been so, from the very beginning of horoscopic astrology. The absence of midheavens in early charts may represent an absence of regard for the significance of the midheaven more than a lack of professional aptitude. It is our contention that this is the case.

Do we have any other evidence? In addition to the charts in Neugebauer and van Hoesen, and a few stray charts that have been reported in other sources, we have a second, rather large, database. These are the charts written on papyrus from Oxyrhynchus in Egypt reported by Alexander Jones. ${ }^{17}$ These charts are fragmentary and often lack some planets as well as the ascendant, midheavens, and intermediate cusps. This appears to be due more to the condition of the surviving papyri, than to the intention of those who wrote down the charts. To add to the database of charts from Neugebauer and van Hoesen, we have tallied these charts as well. For the purposes of our survey we are interested only in those charts which have a computed ascendant or midheaven listed among the positions. We must regard those charts that do not have either point as unknowns. In many cases the listing of the ascendant or midheaven may have been lost in damage to the papyrus. The results of the tally are given below.

\section{Table 1. Tally of Jones' Charts}

\begin{tabular}{lcccc} 
Total & None & Asc. & Mid. & Cusps \\
\hline 81 Charts & 36 & 45 & 4 & 0
\end{tabular}

\footnotetext{
${ }^{16}$ Many ancient texts appear to be ambiguous about the midheaven, not being clear as to whether it is the midheaven in the modern sense, or this point $90^{\circ}$ away from the ascendant.

${ }^{17}$ Alexander Jones, Astronomical Papyri from Oxyrhynchus (Philadelphia, PA, 1999).
} 
Out of 81 charts, 36 have neither ascendants, midheavens, or cusps. Again this may be partly due to the condition of the texts. Of the total of 81 charts, 45 have an explicit or implicit ascendant. By 'implicit ascendant' I refer to charts which, due to damage, had no explicit ascendant listing but contained references to lots, and all of the lots referred to are derived from the position of an ascendant. There were three such charts with lots but no ascendants plus 42 with explicit ascendants for a total of 45 charts. Also one must note that none of the lots in use at that time required the computation of a midheaven. ${ }^{18}$ Given the importance ascribed to lots by most of the Greek sources (Ptolemy excepted), this fact in and of itself suggests the greater importance of the ascendant over the midheaven. Midheavens are found explicitly referred to in only 4 of Jones' charts. Obviously some of this may be due to the condition of the texts, but one cannot attribute the overwhelming difference in numbers between charts with ascendants and those with both ascendants and midheavens to damage alone. One of Jones' charts, \#4261, lists two 'ascendants' but one of the 'ascendants' is clearly either a nonagesimal or a midheaven: one 'ascendant' is listed in Leo and the other in Taurus. No degrees are given so it is impossible to tell which it is. Only one chart lists a midheaven with degrees so that one can say for certain that it is a midheaven and not a nonagesimal. However, there is no real reason for anyone to list a nonagesimal since it is always the ascendant $-90^{\circ}$. Finally, there are no charts with any discernible reference to intermediate cusps. This might suggest Porphyry cusps which require little computation, or it may mean that none of these charts actually used the midheaven as the beginning of the tenth place. We cannot tell for sure.

So we now have a total database of 300 charts. Out of these only 32 have references to midheavens. Only two have intermediate cusps. North states that the "usual way of approaching the historical problem, namely through astrological handbooks can give a very misleading idea of actual

\footnotetext{
${ }^{18}$ In the commentary of Olympiodorus on Paulus Alexandrinus (written $564 \mathrm{CE}$ ) there appears the most comprehensive list of lots from pre-Arabic sources. Of over 100 lots, there are only two that require the midheaven, the lots of strengh and kingship. See Dorian Greenbaum, trans., Late Classical Astrology: Paulus Alexandrinus and Olympiodorus (Reston, VA, 2001), p. 156 (translated from Olympiodorus, Eis ton Paulon <Heliodorou $>$. Heliodori, ut dicitur, in Paulum Alexandrinum Commentarium, ed. E. Boer [Leipzig, 1962], p. 59.6, 16-17.)
} 
practice.... ${ }^{19}$ This seems to valourise surviving charts that may be survivals of actual practising astrologers over those which Neugebauer and Van Hoesen have dubbed 'literary horoscopes', the latter being examples of chart interpretations presented in handbooks as illustrations of technique. North does not address the problem of why astrologers would practice one thing but describe something else in their manuals. But Jones' charts do not appear to be 'literary horoscopes', with the possible exception of a handful of what Jones calls 'Deluxe Horoscopes'. However, these are more likely to be copies of written interpretations provided to astrological clients than they are to be examples for textbooks. And these are a small minority of the charts. What we actually have here is evidence that the 'literary' charts and the non-literary charts were following the same conventions and that was to have charts with an ascendant but not a midheaven.

But, to return to the problem of the unhistorical attitude, I believe that the imputation of laziness, or incompetence, is the result of projecting backwards upon ancient astrological writers the practices of later medieval Arabic and Latin authors, as if somehow the ancients were failing to live up to standards set by later astrologers. The evidence suggests, rather, that the ancients for the most part did something completely different with the places, and only gradually did the convention evolve for using the midheaven in the later sense as the marker for the beginning of the tenth place.

\section{Modus Equalis versus Signs as Places}

Thus far everything we have said leads to two possibilities: these ancient authors used the modus equalis system, or they used the signs as places. According to North, the modus equalis system is to be found in Julius Firmicus Maternus. It is also widely asserted by modern astrologers that this was the method of Ptolemy. Here is the passage in which Firmicus begins his discussion of the computation of the places. ${ }^{20}$

Primus est locus [idest] illa pars, in qua horoscopus est constitutus. In hoc loco vita hominum et spiritus

\footnotetext{
${ }^{19}$ North, p. 6.

${ }^{20}$ The following passages are a slightly edited version of the same argument as it appears in my book, Whole Sign Houses: The Oldest House System (Reston, VA, 2000), pp. 14-15.
} 
continetur, ex hoc loco totius geniturae fundamenta noscuntur, hic locus ab ea parte, in qua fuerit horoscopus, vires suas per residuas partes XXX extendit. Est autem cardo primus et totius geniturae compago atque substantia.

Secundus ab horoscopo locus in secundo signo constituitur et accipit initium a XXX. horoscopi parte et vires suas per XXX residuas partes extendit... ${ }^{21}$

The first place is that portion in which the horoscope is located. In this place are contained the life and breath of human beings. From this place one learns the foundation of the entire geniture. This place extends its powers from that degree in which the horoscope is [located] through the remaining 30 degrees [per residuas partes XXX]. It is, moreover, the first cardine and is the connecting principle and substance of the entire geniture.

The second place from the horoscope is located in the second sign and takes a beginning [initium] from the $30^{\text {th }}$ degree of the horoscope and extends its powers through the remaining 30 degrees...

This text is very ambiguous. The ambiguity comes from the phrase per residuas partes $X X X$, 'through the remaining 30 degrees'. Jean RhysBram translates it as 'through the following thirty degrees'. ${ }^{22}$ If her translation were correct it would establish this as an unambiguous modus equalis system reference. However, the Latin adjective residuus, translated here as 'remaining', does not mean 'following'. It means only 'the remaining' or 'the rest of'. Could it mean all of the other remaining, or the rest of the thirty degrees of a sign rather than the thirty degrees which follow into the next sign? The Latin word initium in connection with the $2^{\text {nd }}$ place does mean 'beginning'. This suggests that the $2^{\text {nd }}$ place begins at the $30^{\text {th }}$ degree of the horoscope. However, what is the ' $30^{\text {th }}$

${ }^{21}$ All references to Firmicus Maternus' Latin text are to the following edition: Julius Firmicus Maternus, Matheseos Libri VIII, eds W. Kroll, F. Skutsch and K. Ziegler (2 vols, Stuttgart, 1968) [hereafter Firmicus, Mathesis]. This reference is to II, 19.2-3 (vol. 1, p. 61). All translations from Latin in this essay are mine.

22 Julius Firmicus Maternus, trans. Jean Rhys Bram, Ancient Astrology - Theory and Practice (Park Ridge, NJ, 1975), pp. 48-51. 
degree of the horoscope'? Is it 30 degrees from the horoscope, i.e., Ascendant, or is the last degree of the horoscope the last degree of the rising sign? 'Horoscopus' can mean the rising sign as well as the rising degree.

Unfortunately I have to say that the text here really is ambiguous. But other sections in the text on the places occupied by lots do not seem to indicate modus equalis places but rather places which are constituted out of the entire sign rather than a 30 degree segment starting at a point within a sign used as a horoscopus. In Book VI, chapter 32, there is the following passage:

Si locum patris partili volueris ratione colligere, et sit diurna genitura, computes a parte Solis usque ad partem Saturni omnem partium numerum, omnium scilicet signorum quae a Sole usque ad Saturnum sunt, et cum integram numeri feceris summam, ab horoscopi parte incipiens hunc numerum qui completus fuerit signis omnibus divides, reddens triginta partes singulis signis; et in quo signo novissima pars ceciderit, ipsum tibi signum locum patris monstrat. ${ }^{23}$

If you should desire to acquire the place of the Father by a method exact to the degree, and it is a diurnal geniture, you will compute the number of all of the degrees from the degree of the Sun as far as to the degree of Saturn, to wit, of all of the signs which are from the Sun to Saturn. And when you have established the entire sum of that number, beginning from the degree of the horoscope, you will divide this number which had been arrived at among all the signs giving thirty degrees to the individual signs. And in whichever sign the last degree falls, that very sign reveals the place of the father.

Here the text unambiguously defines a 'place' as a sign, not any thirtydegree patch. There is no 'interpretation' of the Latin here.

So why should Firmicus use the modus equalis method for places determined from the ascendant and then use signs as the places for the lots?

Now we come to Ptolemy. He also presents difficulties. The problem here is that our earliest Greek manuscripts are rather far removed from

${ }^{23}$ Firmicus, Mathesis VI, 32.3, vol. 2, p. 175. 
ancient times and quite possibly have been tinkered with by astrologically aware copyists who have made changes. ${ }^{24}$ However, even if we take the text as it has been edited by modern scholars, we find that Ptolemy does not present simple, straightforward solutions. This very ambiguity of Ptolemy, we have reason to believe, is the source of much technical change in astrology, especially as it pertains to the computation of the places.

Here is the first passage in question. This is the passage which has caused many to believe that Ptolemy used the modus equalis. I use here the Robbins translation followed by an analysis of the Greek version from the Boer-Boll edition. It has to do with computing the aphetic point (aphetês) of the chart, that is, a point which has to do with computing the basic vitality of an individual and relates to life expectancy. This has been one of the most confused pieces of lore in all of the history of astrology. The confusion begins here: ${ }^{25}$

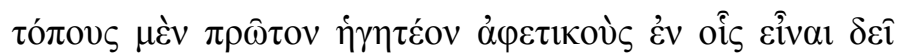

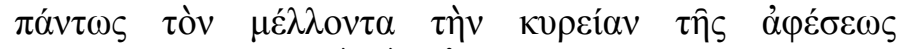

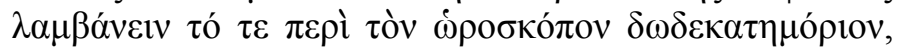

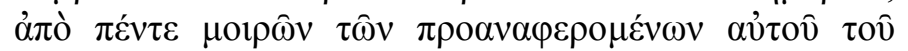

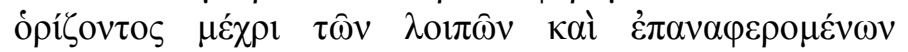

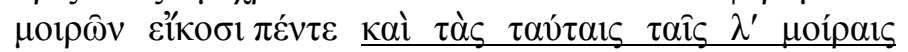

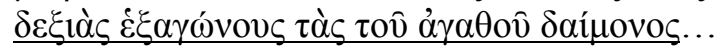

In the first place we must consider those places prorogative [aphetikous] in which by all means the planet must be that is to receive the lordship of the prorogation; namely, the twelfth part [dódekatēmorion ${ }^{26}$ of the zodiac

${ }^{24}$ See David Pingree, 'Antiochus and Rhetorius', Classical Philology (1977), vol. 72 , no. 3 , p. 203.

25 This and other points regarding Ptolemy and place computation are made by myself and Robert Schmidt in the Introduction and body of Schmidt's translation of Ptolemy. See Claudius Ptolemy, Tetrabiblos, Book III, trans. Robert Schmidt (Berkeley Springs, WV, 1996) [hereafter Schmidt]. I especially refer the interested reader to my Introduction, p. ii, and Schmidt's Translator's Preface, pp. viii-xiv.

${ }^{26}$ This term is part of the confusion in Ptolemy. Where other authors use the

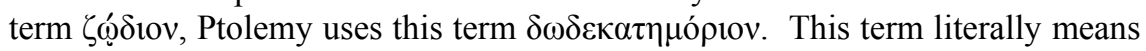

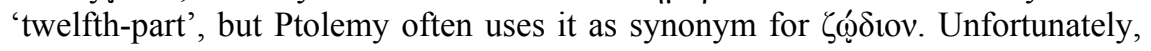


surrounding the horoscope, from $5^{\circ}$ above the actual horizon up to the $25^{\circ}$ which remains, which is rising in succession to the horizon; the part sextile dexter to those thirty degrees, called the House of the Good Daemon... ${ }^{27}$

The underlined portion is the problematical part. First of all, the phrase 'the House of' does not appear in the Greek. The Greek is simply tov

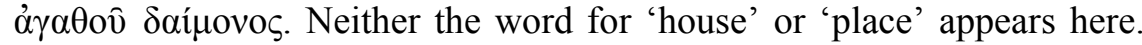
Let us look at the Greek of the underlined passage:

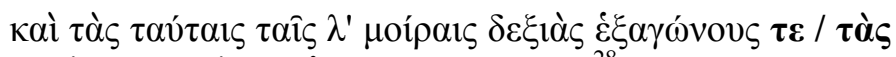

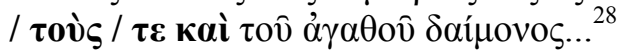

The words in bold type (separated by slashes) are the critical ones. Each one is an alternative to the others according to Boer who edited the 1957 Teubner edition of the Tetrabiblos. Robbins favoured $\tau \varepsilon$, and Boer $\tau \dot{\alpha} \zeta$. Wolfgang Hübner, who edited the most recent Teubner edition, also favoured $\tau \grave{\alpha} \varsigma_{.}{ }^{29}$ But the upshot of all of these is that it is up to the choice of the editor of the Greek to interpret exactly what Ptolemy was saying here. Here are the two basic choices: 1) One set of interpretations (= $\tau \grave{\alpha} \varsigma)$ states that the 30 degrees which are in a right hexagon (sextile) to the ones around the Ascendant are also known as the 'Good Daimon' or $11^{\text {th }}$ topos or place. 2) The other possible set of interpretations (= $\tau \varepsilon \kappa \alpha \grave{i})$ says that the degrees in question must be from among those 30 degrees which are in the right hexagon and which are also in the $11^{\text {th }}$ place, however that place is to be computed. Thanks to the textual confusion we do not

he also uses it to mean any group of thirty contiguous degrees not necessarily lying within one sign. Other authors use the same term to designate the subdivision of the signs into either twelve or thirteen parts. For this last see Greek Horoscopes, p. 6.

${ }^{27}$ Ptolemy, Tetrabiblos, trans. F.E. Robbins (Cambridge, MA, 1954) [hereafter Robbins], p. 273. Greek from the Boer-Boll edition: Claudius Ptolemy, AПOTE $\triangle$ ЕMATIKA, eds E. Boer and F. Boll (Leipzig, 1940, repr. 1957) [hereafter Boer-Boll], III, 11.3, p. 129.15-21.

${ }^{28}$ Boer-Boll, p. 129.

29 Claudius Ptolemy, Claudii Ptolemaei opera quae exstant omnia, AПОTЕАЕ $М$ МTIKA, ed. Wolfgang Hübner (vol. III, 1, Stuttgart/Leipzig, 1998) [hereafter Hübner], III, 11.3, p. 203.567. 
know from the Greek whether these degrees constitute the $11^{\text {th }}$ place (which favors the modus equalis interpretation), or whether the degrees in question have to be both in the $11^{\text {th }}$ place, however it is to be computed, and in sextile as well to the degrees around the Ascendant. ${ }^{30}$ But finally what we have here in Ptolemy is not a description of a system of places, but a description of locations or degrees in the chart in which an aphetic point may be found.

There is another place where Ptolemy can be read in a number of ways depending on the choices of the editor of the Greek. In the chapter on siblings in Book III of the Tetrabiblos (III, 5 in Robbins and III, 6 in Boer-Boll, Hübner and Schmidt) we have the following passage as rendered by Robbins:

...it is more naturally to be taken... from the culminating sign, the place of the mother, that is, that which contains by day [diurnal chart] Venus and by night [nocturnal chart] the Moon. [Bracketed material supplied by author. $]^{31}$

Here is the Greek of the passage as edited by Robbins:

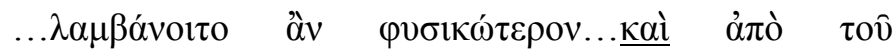

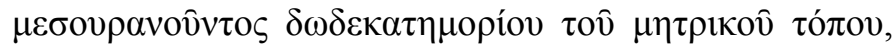

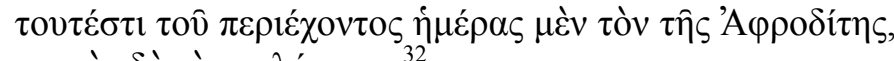

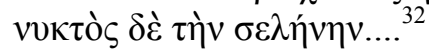

The underlined kaì is not in the Boer edition, which is not germane here, but Robbins indicates that some editions do place a кaì after dōdekatēmoriou. ${ }^{33}$ As Robbins points out, this would make the English 'from the culminating sign and the place of the mother'. ${ }^{34}$ As Robbins

\footnotetext{
${ }^{30}$ Again see Schmidt's Translator's Preface to Book III of the Tetrabiblos and to the translation of chapter 11, pp. 29-33.

${ }^{31}$ Robbins, p. 251.

${ }^{32}$ Boer-Boll, p. 120.

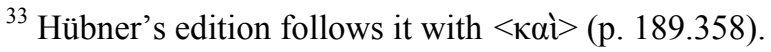

${ }^{34}$ Robbins, p. 251, n. 1.
} 
also points out, this is an exceedingly difficult passage. However, there is yet another reading. If we take the Greek of 'the culminating sign, the place of the mother' and make the phrase 'the place of the mother' not an apposition as Robbins would have it, but instead make it modify the phrase 'the culminating sign', we would get the following English:

...it is more naturally to be taken...according to that which culminates with respect to sign of the place of the mother, that is, that [place] which contains by day Venus and by night the Moon.

This reading makes the place of Venus by day, or the Moon by night function as an horoscopus from which one computes a culminating place by moving ahead $270^{\circ}$ from the degree of Venus or the Moon and taking the following $30^{\circ}$ as the culminating place (a modus equalis approach), or by moving ahead to the tenth sign from the sign of Venus or the Moon (the sign-as-place approach). Again we are prevented from knowing which by Ptolemy's use of the word, dōdekatēmorion, 'twelfth part'.

In other passages where we see Ptolemy apparently referring to places/houses in the modern sense, we either have adjectives with no explicit nouns, or we have more references to dódekatemoria. Ptolemy could have used either the modus equalis or the sign-as-place system which we have already encountered in connection with the places of lots in Julius Firmicus Maternus.

So we have the two props of the modus equalis system in the ancient world, Ptolemy and Firmicus, rendered ambiguous, possibly hopelessly, in the case of the first, and dubious in the case of the second.

\section{Signs as Places in regard to Significations in Vettius Valens}

When we turn to Vettius Valens we find two things that are of interest. First, Valens does explicitly refer to midheavens and, while his calculation technique may be not quite correct, his midheavens can be shown not to be nonagesimals. In III, 2 of the Anthology, Valens describes a method of computing places which is the same as that later attributed to Porphyry, as mentioned above. In this system, the distance in degrees between the ascendant and midheaven in longitude is divided into three equal parts, which become the $10^{\text {th }}, 11^{\text {th }}$, and $12^{\text {th }}$ places. Then the same is done between the ascendant and IC to get the $1^{\text {st }}, 2^{\text {nd }}$, and $3^{\text {rd }}$ places. Here is the passage, with Robert Schmidt's translation (slightly modified): 
150 Signs as Houses (Places) in Ancient Astrology

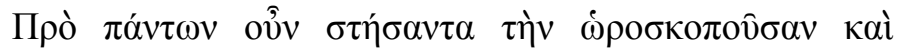

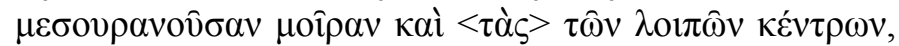

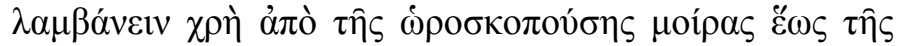

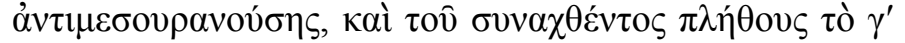

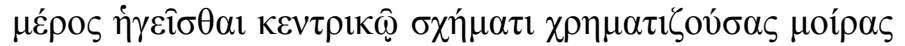

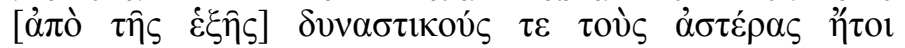

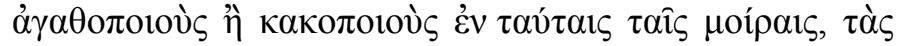

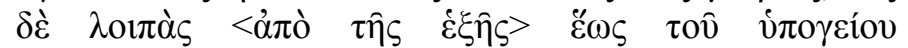

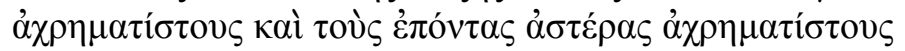

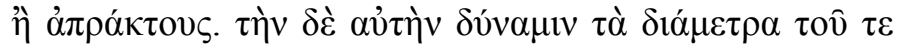

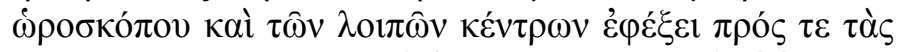

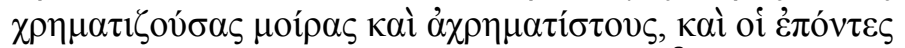

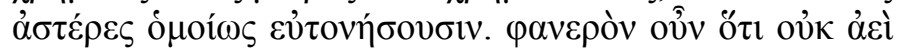

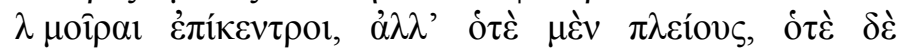

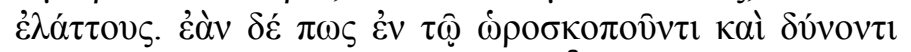

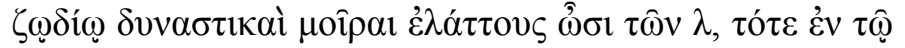

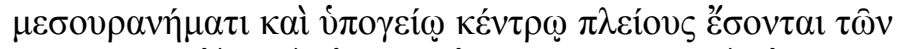

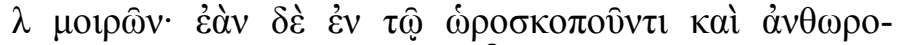

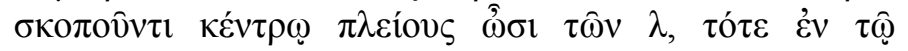

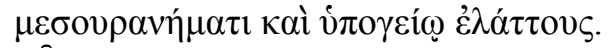

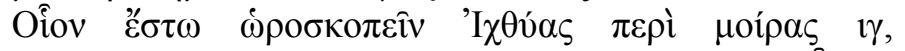

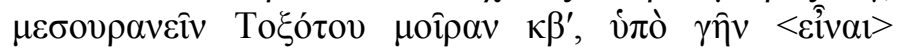

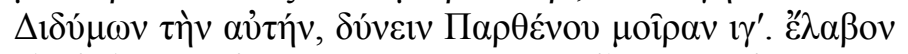

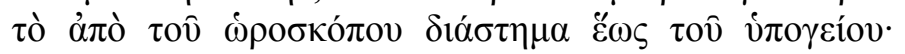

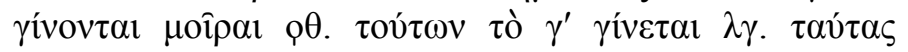

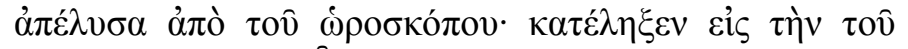

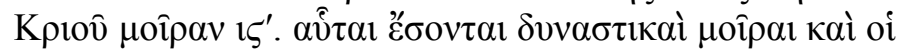

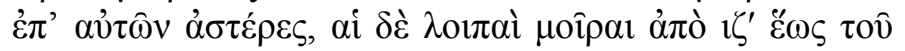

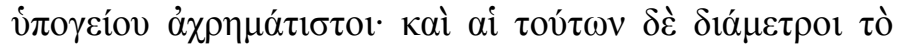

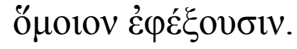

Before all, then, after one has established the degree marking the hour [horoscopus] and the degree culminating and the degrees of the remaining pivot points, it behooves him to take the interval from the degree marking the hour up to the degree anticulminating, and to suppose that $1 / 3$ part of the sum in the pivotal figure consists of profitable degrees, and that either benefic or malefic stars are powerful in these degrees. But one must also suppose that the remaining 
degrees [from the next degrees] up to the subterraneous pivot point are unprofitable and the stars upon them profitless and ineffectual; and that the diameters [i.e. oppositions] of the Horroskopos and the remaining pivot points possess the same power in relation to the profitable and unprofitable degrees, the stars upon them being likewise vigorous. Now, it is clear that there are not always 30 degrees upon a pivot point, but sometimes more and sometimes fewer. And if the powerful degrees in the zoidia marking the hour and setting should be fewer than 30, then there will be more than 30 degrees in the Midheaven and the subterraneous pivot point. And if there should be more than 30 degrees in the pivot point marking the hour and the one opposite this, then there will be fewer than 30 degrees in the Midheaven and the subterraneous pivot point.

For example, let Pisces be marking the hour at 13 degrees, the 22nd degree of Sagittarius culminating, the same degree of Gemini being under the earth, and the 13th degree of Virgo setting. I took the interval from the Hóroskopos to the subterraneous pivot point; it comes to 99 degrees. The $1 / 3$ part of these is 33 . I departed with these from the Horoskopos. It left off at the 16th degree of Aries. These degrees and the stars upon them will be powerful, but the remaining degrees from the 17th degree up to the subterraneous place will be unprofitable. And their diameters will hold sway in the same manner. ${ }^{35}$

In this description Valens mentions only the power of the degrees, profitable or unprofitable, in each place; he says nothing about the signification, i.e., what part of life each place rules.

This system was also described in the Thesaurus of Antiochus of Athens in chapter $46,{ }^{36}$ but again the use is in connection with computing the years associated with each place and not with the signification. The

\footnotetext{
${ }^{35}$ Vettius Valens, Anthology, Book II (concl.) \& Book III, trans. Robert Schmidt (Berkeley Springs, WV, 1994), III, 2, pp. 33-34 (= pp. 127.17-128.3 Pingree).

${ }^{36}$ See note 6.
} 
introduction to Ptolemy, ascribed to Porphyry, quotes Antiochus, and that is how the system came to be called the 'Porphyry' house system.

Later on in the Anthology Valens comes back to the issue of the midheaven and makes it clear that he does not make the midheaven the beginning of the tenth place. This passage is in Book $\mathrm{V}$, chapter 6 of Valens' Anthology. Here Valens mentions what happens when Gemini rises and the midheaven happens to fall into Aquarius. (This is a situation which cannot happen if the midheaven is equated with the nonagesimal.) He states that in such a case Aquarius has to do double duty. It becomes a place of action, the function of the culminating place, because the midheaven falls into it, but it remains the place of foreign lands and 'God' (the Greek name for the $9^{\text {th }}$ place). Similarly, Leo at the other end does service both as the sign of the IC and as the $3^{\text {rd }}$ place from the Ascendant. ${ }^{37}$ The references here, unlike Ptolemy, are unambiguously to zóidia serving the function of places, not $30^{\circ}$ sections of contiguous degrees that may or may not (usually do not) coincide with a zodiacal sign.

Oîov $\Delta 1 \delta$ $\delta$ ors

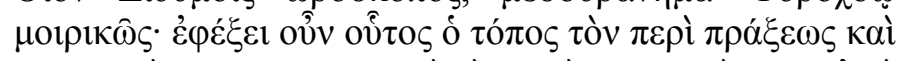

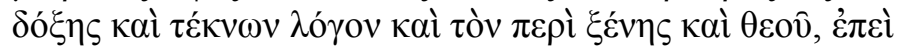

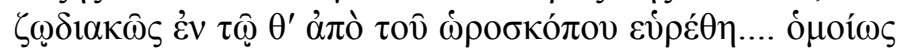

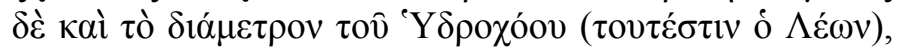
ö $\varepsilon \rho$ vं

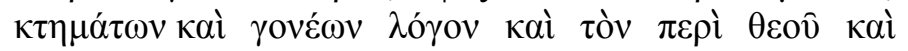
$\dot{\alpha} \delta \varepsilon \lambda \varphi \hat{\omega} v \kappa \alpha \grave{\xi} \xi \dot{\varepsilon} v \eta \varsigma . .$.

As with the Hōroskopos in Gemini, the Midheaven in Aquarius by degree. This place, then, possesses the relation concerning activity and reputation and children [tenth place functions], and also that concerning a foreign land and god [ninth place functions] since zodiacally it is found in the $9^{\text {th }}$ from the Horroskopos.... Similarly also, the diameter of Aquarius (that is, Leo), which is the subterraneous pivot, possesses the relation concerning foundations, buildings, and parents [fourth place

${ }^{37}$ Vettius Valens, Anthology, Books $V \& V I$, trans. Robert Schmidt (Berkeley Springs, WV, 1994), p. 30. 
functions], as well as that concerning god and siblings and a foreign land [third place functions]... ${ }^{38}$

Here at the very least we see a synthesis between the later type of place division and what we maintain is the earlier type in which the signs themselves are the places.

When we look elsewhere in Valens, it is sometimes hard to see exactly what he is doing regarding the allocation of places. Most of the charts do not give degrees or minutes for the positions of any of the points in the chart including the horoscopus. In the ones where he does give positions within the signs (and these charts also include midheavens) there is no unambiguous reference to positions of planets in places that would give a clear idea of where his places begin and end. However, one can deduce what he is doing even in the charts where no degree positions are given from the following simple fact. If Valens were using modus equalis or the Porphyry system, then there would be occasions where planets would be listed as in different places than one would expect if he were using the signs as places. Here is an illustration based on chart no. L 37 from Greek Horoscopes. ${ }^{39}$

Table 2. Chart L37

\begin{tabular}{|c|c|c|c|}
\hline \multicolumn{2}{|c|}{ Text } & G. $H$. & Program \\
\hline$\odot$ & $x$ & $23 \not$ & $23 x$ \\
\hline$\sigma^{r}$ & $x^{\prime}$ & $27 x^{7}$ & $26 x^{7}$ \\
\hline$\not \varnothing$ & $x^{\prime}$ & $1 x^{\nearrow}$ & $1 x$ \\
\hline$\stackrel{+}{\mathrm{H}}$ & $x^{7}$ & sunrise & $23 x$ \\
\hline D & $\Omega$ & $9 \Omega$ & $13 \Omega$ \\
\hline$\hbar$ & $m p$ & $27 \mathrm{mP}$ & $27 \mathrm{ml}$ \\
\hline 2 & $m$ & $14 m$ & $15 \mathrm{~m}$ \\
\hline q & ks & 2419 & $23 \mathrm{~kg}$ \\
\hline
\end{tabular}

The data are as follows: about sunrise, 15 December 37 CE. Since we know that this is the chart of the emperor Nero, we know that the place is

\footnotetext{
${ }^{38}$ Ibid. (=V, 6.66-67; p. 215.29-31, 34-36 Pingree).

${ }^{39}$ This chart is in Valens V, 7.20-35 (= pp. 222-23 Pingree).
}

Culture and Cosmos 
Rome. ${ }^{40}$ The table at the right gives Valens' positions, followed by those computed by the authors of Greek Horoscopes, then those computed by a modern program. ${ }^{41}$ The differences between the calculations in Greek Horoscopes and those of our computer program are due to the following factors. The program used is based on state of the art modern astronomical algorithms vastly more accurate than what was available to Neugebauer and Van Hoesen. Second, we follow the standard astrological practice of rounding up to the next degree unless the position is exactly 0 minutes of arc. Third, the discrepancy in the case of the Moon is due to delta $\mathrm{T}$, the difference between observable mean solar time and atomic time. This value cannot be known for certain this far back in history and amounts to several hours difference. If Neugebauer and Van Hoesen took it into consideration at all, their value would be likely to be different from our value, and in any case we have no way of knowing one way or another. ${ }^{42}$

In this chart Valens gives no degree positions and makes no reference to house positions. I offer this chart simply as an example of what would have happened if he had. The following table gives the cusps of the places as they would have been if Valens had used either modus equalis or Porphyry.

Table 3. Cusps of the Places According to Modus Equalis and Porphyry Methods

\begin{tabular}{|c|c|c|c|c|c|c|c|c|c|c|c|c|}
\hline Places & 1 & 2 & 3 & 4 & 5 & 6 & 7 & 8 & 9 & 10 & 11 & 12 \\
\hline M.E. & $\begin{array}{l}23 \\
x\end{array}$ & $\begin{array}{l}23 \\
19\end{array}$ & $\begin{array}{l}23 \\
\approx\end{array}$ & $\begin{array}{l}23 \\
H\end{array}$ & $\begin{array}{l}23 \\
\Upsilon\end{array}$ & $\begin{array}{l}23 \\
\succ\end{array}$ & $\begin{array}{l}23 \\
\square\end{array}$ & $\begin{array}{l}23 \\
9\end{array}$ & $\begin{array}{l}23 \\
8\end{array}$ & $\begin{array}{l}23 \\
m p\end{array}$ & $\begin{array}{l}23 \\
\bumpeq\end{array}$ & $\begin{array}{l}23 \\
m\end{array}$ \\
\hline Por. & $\begin{array}{c}23 \\
x\end{array}$ & $\begin{array}{l}30^{*} \\
19\end{array}$ & $\begin{array}{r}8 \\
H\end{array}$ & $\begin{array}{l}16 \\
\Upsilon\end{array}$ & $\begin{array}{r}8 \\
\succ\end{array}$ & $\begin{array}{l}30^{*} \\
\succ\end{array}$ & $\begin{array}{l}23 \\
\square\end{array}$ & $\begin{array}{l}30^{*} \\
6\end{array}$ & $\begin{array}{r}8 \\
m p\end{array}$ & $\begin{array}{l}16 \\
\bumpeq\end{array}$ & $\begin{array}{c}8 \\
m\end{array}$ & $\begin{array}{l}30^{*} \\
\mathrm{~m}\end{array}$ \\
\hline
\end{tabular}

* 30 means that the position is $29^{\circ}+$ but less then $0^{\circ}$ of the next sign.

\footnotetext{
${ }^{40}$ The actual data are to be found in Suetonius' Lives of the Twelve Caesars in the chapter on Nero.

${ }^{41}$ Solar Fire version 5.1.

${ }^{42}$ See Robert R. Newton, Ancient Planetary Observations and the Validity of Ephemeris Time (Baltimore, 1976) for discussion of the problem. For our purposes, ephemeris time and atomic time may be regarded as identical.
} 
Now, if we tabulate the positions of the planets in the places (using the modern computed positions), we get the following results for signs-asplaces, modus equalis, modus equalis $-5^{\circ}$, Porphyry, and Porphyry $-5^{\circ}$. The tabulations of the cusps of the places less five degrees is what the results would have been if the custom of beginning a place five degrees prior to the cusp were being used. ${ }^{43}$ (This was not done with signs-asplaces.)

Table 4. Tally of the Planets in the Places According to the Different Systems

\begin{tabular}{l|r|r|r|r|r|r|r} 
Planets & \multicolumn{1}{|c|}{ D } & \multicolumn{1}{c|}{+} & \multicolumn{1}{c}{ ㅇ } & \multicolumn{1}{c|}{$\odot$} & \multicolumn{1}{c|}{ ๙ } & \multicolumn{1}{c}{4} & ち \\
\hline Signs & 9 & 1 & 2 & 1 & 1 & 12 & 10 \\
\hline M.E. & 8 & 12 & 2 & 1 & 1 & 11 & 10 \\
\hline M.E. -5 & 8 & 12 & 2 & 1 & 1 & 11 & 10 \\
\hline Por. & 8 & 12 & 2 & 1 & 1 & 11 & 9 \\
\hline Por. -5 & 8 & 12 & 2 & 1 & 1 & 11 & 9 \\
\hline
\end{tabular}

Notice that with the various types of place definition there are many shifts of planets from one place to another, especially regarding the signs as places. If Valens were using anything other than signs as places, then one would expect planets to be listed in places other than those that one would expect using that system. I have not found any such instance in the charts given in Greek Horoscopes. Therefore, we have to assume that Valens never used any of these other systems. He did not merely leave out the midheavens and intermediate cusps; he did not use them except possibly in the specialized way mentioned above.

\section{Two More Charts from Greek Horoscopes}

Now let us turn to two more 'literary' charts from Greek Horoscopes which are from sources other than Valens, L -42 , and L 40. The first of these is one of the earliest dates for which a chart has been found from

\footnotetext{
${ }^{43}$ This practice, insofar as it was used, was derived from the material cited above in Ptolemy, Book III, regarding the aphetic places.
} 
Robert Hand 157

Table 5. Chart L 40

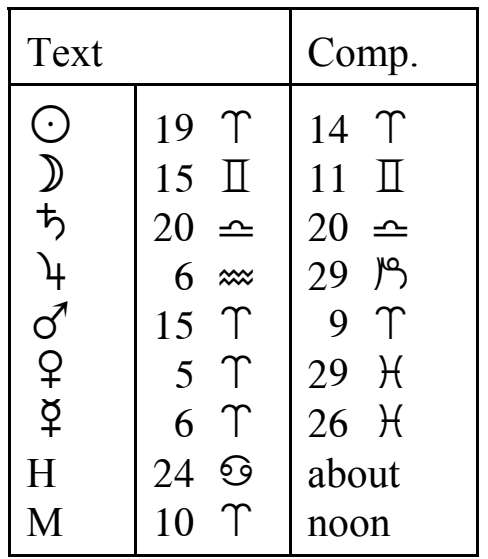

Our second chart, L 40, is one of two attributed to Antigonus of Nicaea from Hephaestio. ${ }^{48}$ It corresponds to about noon of 5 April $40 \mathrm{CE}$ and is possibly the chart of one of the family of the emperor Hadrian. This chart has a midheaven which suggests that the places might be computed by the Porphyry method. However, the text says that he was 'very distinguished because of four stars $\left(\odot, \sigma^{*}, \quad\right.$, $\left.\varnothing\right)$ being in the Midheaven $(\Upsilon)^{\prime}$. By Porphyry it is not clear that Venus or Mercury is in the tenth place, Mercury being 4 degrees prior to the cusp, and Venus 5. If the chart has places computed according to the modus equalis, they would be even further from the tenth place. Although this could be an instance of the 5 degree rule, there is also no question that these planets would be unambiguously in the tenth place using the signs as houses, all of Aries being the tenth place.

\section{Later Examples}

A possibly later example of signs as places is to be found in the Liber Hermetis. I say 'possibly later' because it is hard to date the text. The Liber Hermetis appears to be an anthology of classical texts compiled by someone in the Middle Ages, and then translated into Latin. Many of the passages contained in this work are translations of Valens. One of the chapters of unknown provenance is chapter 26 where we have the following passage:

\footnotetext{
${ }^{48}$ Greek Horoscopes, pp. 79-80. From Hephaestio, Apotelesmatika II, 18.54-61 (pp. 163-64 Pingree).
}

Culture and Cosmos 
158 Signs as Houses (Places) in Ancient Astrology

Sol in ascendente non infortunatus in diurna nativitate, maxime in domo propria vel triplicitate aut exaltatione, patris nobilis natum ostendit et natum in propria patria divitiis et possessionibus glorificari. Plures autem et reges facti sunt cosmocratores, i.e., mundum tenentes sive regentes, alii vero duces seu praesides....

In nocte vero Sol in ascendente patris pauperis vel ignobilis vel expulsi natum ostendit aut servi aut domum paternam destruet; quandoque vero patris orphanitatem et nati vitam laboriosam facit et sine gloria.... ${ }^{49}$

The Sun in the ascendant in a diurnal nativity, not rendered unfortunate, especially [if it is] in its own domicile or exaltation or triplicity, shows one who has been born of a noble father and who is glorified in his own country with riches and possessions. Most of these, moreover, have become kings who are cosmocrators, i.e., those who possess or rule the world, but others become dukes or those who preside [in some other way] ...'

But in the night the Sun in the ascendant shows one born of a father who is poor, ignoble, or who has been exiled or is a slave, or the native himself will destroy the paternal household and sometimes in fact it causes the loss of the father and the life of the native to be in suffering and without glory.

There are only two ways that the Sun can be in 'in the ascendant' in a diurnal nativity. If the astrologer followed the 'five degree' rule advocated by some on the basis of Ptolemy then the Sun could be up to five degrees above the horizon which would make the chart diurnal, yet the Sun would still be in the ascendant. But as we have pointed out previously, it is not clear how widespread that practice was. However, the other way that the Sun could be above the horizon in the ascendant is with the use of signs as places. If the horoscopus is in the late degrees of a sign, and the Sun in the early degrees, then the condition would be met.

\footnotetext{
${ }^{49}$ Wilhelm Gundel, Neue Astrologische Texte des Hermes Trismegistos (Munich, 1936), p. 73 (= Hermetis Trismegisti de triginta sex decanis, ed. Simonetta Feraboli, Hermes Latinus Tome IV, part 1 [Turnhout, 1994], XXVI, 5, 8, pp. 135.23-28, 136.34-36).
}

Culture and Cosmos 
The practice of using signs as places did not die out at the end of the Greek era. We also find it in early Arabic era authors such as Masha'allah (fl. 762-815). In fact, the instances where we find the signs as places in the Arabic literature are much less ambiguous than they are in the Greek. Here is an instance. The following example from Masha'allah's $O n$ Reception, an early work on interrogations, illustrates the use of signs as places in early Arabic astrology.

Et si esset Luna in septimo angulo, fieret utique res velocior, et si esset cum Saturno in decimo signo, esset adhuc velocius. Et in signo ascendente esset velocius prae caeteris locis. ${ }^{50}$

And if the Moon had been in the seventh angle, the matter would have certainly been accomplished more quickly; and if she had been with Saturn in the tenth sign, it would have been still more swift; and in the ascending sign it would be the most swift above all other places.

Notice that the signs are referred to as if they were places. The Latin is signum, not locus. And this usage also occurs in Masha'allah's work De Revolutione Annorum Mundi.

Scito quod fortior ex planetis est ille, qui fuerit in ascendente, non remotus ab angulo, neque cadens, vel qui fuerit sic in medio coeli, in occasu vero et angulo terrae, erit inferius quam dixi tibi in fortitudine per quartam partem. Et signum undecimum est infra occasum et angulum terrae, et nonum infra undecimum, et quintum infra nonum, et tertium infra quintum. ${ }^{51}$

Understand that the strongest of the planets is that planet which is in the Ascendant not remote from the angle, nor cadent, or [a planet] which is like this in the Midheaven.

\footnotetext{
${ }^{50}$ Māshā'allāh, De Receptione, trans. John of Seville (Nuremberg, 1549), chapter $\mathrm{X}$, no pagination.

51 Māshā'allāh, De Revolutione Annorum Mundi, trans. John of Seville (Nuremberg, 1549), chapter VI, no pagination.
} 
160 Signs as Houses (Places) in Ancient Astrology

But in the West or in the Angle of the Earth that [power] which I have described to you will be lower in strength by a quarter part. And the eleventh sign is below the West [in power] and the Angle of the Earth and the ninth sign is below the $11^{\text {th }}$, and the fifth sign is below the $9^{\text {th }}$, and the third sign is below the fifth.

In the earliest Latin astrological texts of Arabic origin (10th century) we find the same equivalence of sign and house. ${ }^{52}$

\section{Conclusions}

Many other examples can be adduced from Greek and early Arabic sources, but this will have to do for the purposes of this paper. However, an interesting question remains: has this method of using the signs as places survived in any branch of the astrological tradition? The answer is a resounding yes! It was in fact the knowledge of this that caused several of us involved in the study of Greek astrology to be on the alert for the possibility that it was a practice among the Greeks, especially Ptolemy. For, to this day the use of signs as places is the dominant system of place computation in the astrology of India and all other traditions derived from it. ${ }^{53} \mathrm{~A}$ chart constructed in this manner is known as the rasi chakra. ${ }^{54}$ Having encountered this practice, and believing that the further one goes back into horoscopic astrology, the more likely one is to see a convergence between Hindu and Middle Eastern/Western astrology, it

\footnotetext{
${ }^{52}$ See David Juste, Les Alchandreana primitifs (Leiden, 2007), pp. 126-7.

53 In fact there are two common systems of place computation in Indian astrology, the use of signs as houses, and another system which has the same basic math as the so-called Porphyry system. It called the system of Sripati. The main difference between it and the Porphyry system is that the cusps of the places do not indicate the beginnings of the places, but the middles. See de Luce cited in the next note.

${ }^{54}$ While just about every Hindu astrologer I have read uses this system, not every text is clearly explicit about its use. One of the better modern texts for our purposes is Robert de Luce, Constellational Astrology (Los Angeles, CA, 1963). See pp. $51 \mathrm{ff}$. for a discussion of Hindu place division, here referred to in the customary modern fashion as 'houses'. De Luce is most useful because he more frequently cites the traditional Hindu texts than other modern authors.
} 
was natural for us to look at Ptolemy and the other Greeks to see if they, too, used signs as places. ${ }^{55}$

To sum up, the frequent lack of midheavens in Greek horoscopes and later, I suggest, is not due to ineptitude or laziness on the part of ancient astrologers but is due to a completely different rationale of reckoning places which did not require a midheaven; nor did it, as Valens shows, preclude the use of the midheaven. The basic principles of the system were as follows:

1. There was only one way in which the chart was divided into twelve divisions, the signs of the zodiac. The places were simply the signs counted from the rising sign.

2. The sign of the horoscopus, the entire sign from $0^{\circ}$ to $30^{\circ}$, was the first place. The function of the horoscopus (and also of the Lot of Fortune) was to mark which sign was to be regarded as the first place.

3. If a midheaven was computed, it was allowed to float and could be found in the $9^{\text {th }}, 10^{\text {th }}$, or $11^{\text {th }}$ sign from the horoscopus, and when it did so, it gave whatever place it fell into some of the signification of the $10^{\text {th }}$ place. ${ }^{56}$

4. The Lot of Fortune (and other lots as well) could also mark place systems for specialized purposes of interpretation. We see this most completely laid out in Vettius Valens. In Ptolemy there is evidence that the same was done with some of the planets, the sign of the Sun and Saturn for the father, and the sign of Venus and the Moon for the mother.

It is our conviction that the use of signs as places is the oldest place method. Only gradually did the midheaven, first, come to be used at all, and, second, come to be the cusp or defining point of the tenth place. The oldest reference that we have that mentions this kind of division at all is Valens, and even with him there is little evidence that he used it in the way that came to be the norm. Then we have Ptolemy whose work left so many questions. It has been said that astrology has evolved little since

\footnotetext{
${ }^{55}$ On this convergence see David Pingree, The Yavanajataka of Sphujidhvaja (2 vols, Cambridge, MA, 1978). See especially the commentary in volume 2.

${ }^{56}$ In more extreme latitudes the midheaven may fall in the twelfth or eighth sign from the ascendant as well.
} 
Ptolemy. But if one looks at the texts of his time, and those that followed, it becomes clear that astrology has evolved quite a bit, and it is not clear that he was even typical of his time. Even those who claimed to follow Ptolemy, especially in the early modern era ${ }^{57}$ had to use elements derived from other sources simply because Ptolemy's system is incomplete as an astrological system.

Finally, whatever one may think of astrology in general and Greek astrology in particular, some of the practitioners were very learned men. ${ }^{58}$ We should assume, therefore, that what they did, they did intentionally. We should not evaluate the integrity of ancient astrology based on criteria derived from a backward projection of later medieval and early modern astrological techniques onto the ancients. They must be evaluated on their own terms.

\footnotetext{
${ }^{57}$ Girolamo Cardano (1501-1576) and Placidus de Titis (1603-1668) are the two best known examples of early modern astrologers who attempted to implement a complete 'back to Ptolemy' program, and, while their astrology incorporates many elements of a peculiarly Ptolemaic kind, their astrology was far short of completely Ptolemaic.

${ }^{58}$ Thrasyllus, astrologer to the emperors Tiberius and Caligula was an important Platonist and the first editor of Plato's complete works. And, of course, there was Ptolemy.
}

Culture and Cosmos 